\title{
Happiness in the Garden of Epicurus
}

\author{
Ad Bergsma · Germaine Poot $\cdot$ Aart C. Liefbroer
}

Published online: 28 February 2007

(C) Springer Science+Business Media B.V. 2007

\begin{abstract}
Epicurus was a philosopher who lived in Greece in the 3rd century B.C. Like his contemporaries, he was much concerned with the question of how to live a good life. In his view the Chief Good is to decrease pain and increase pleasure. Though Epicurus is reputed for advocating the pursuit of refined sensorial pleasures, he recognized the need for deferring gratification or enduring pain. He advised his followers to lead a modest and contemplative life in friendly communities. His advice can be characterized as 'serene hedonism'. This paper explains that position and considers its applicability for the present day. It concludes that Epicureanism was quite accurate in describing the conditions of happiness and that he offered valuable guidelines in dealing with hardship and difficult emotional content. His ideas that happiness is the same as the absence of pain and that one should withdraw from society are less fortunate. It made him assume that happiness automatically follows if one is in the right state of mind, and that there is no need to actively seek interaction with the environment for the betterment of the circumstances of life. However, Epicurus' advice might have been a good option for his contemporaries given the societal turmoil in his times.
\end{abstract}

Keywords Epicurus $\cdot$ Happiness $\cdot$ Advice $\cdot$ Ascetic $\cdot$ Hedonism · Marriage $\cdot$ Life style

\author{
A. Bergsma $(\bowtie)$ \\ Faculty of Social Sciences, Erasmus University Rotterdam, P.O. Box 1738, \\ 3000 DR Rotterdam, The Netherlands \\ e-mail: bergsma@fsw.eur.nl \\ G. Poot \\ University for Humanistics, P.O. Box 797, 3500 AT Utrecht, The Netherlands \\ e-mail: gcpoot@hotmail.com
}

\section{A. C. Liefbroer}

Amsterdam \& Netherlands Interdisciplinary Demographic Institute, Vrije Universiteit, P.O. Box 11650, 2502 AR The Hague, The Netherlands

e-mail: ac.liefbroer@fsw.vu.nl 


\section{Introduction}

More than 2000 years ago, in the Greek world, many philosophers occupied themselves with the question, What makes our lives happy? Most of these antique philosophies, like the systems of Plato, Aristotle and the Stoa, not only produced theory on this subject, but also promised happiness to those who were willing to accept their viewpoints (Algra, 1998a, pp. 18-19.) Among these great philosophical systems Epicurus' philosophy stands out because it is a view that identifies happiness with pleasure and is the one among the ancient versions of hedonism that is best known and to which attention is still paid.

Epicurus' philosophy, formulated in the third century B.C., gave its followers the prospect of personal happiness and took almost religious proportions; the adherents lived in small communities and the founder of this school was worshipped as a deity. His life was considered exemplary. There are some indications that Epicurus was successful in living his own philosophy, and he gave clear, understandable advice on how to achieve personal happiness. Moreover, he claimed to have founded his philosophy on empirical facts. His philosophy about the good life brought Epicurus fame that has lasted till the present day. Epicureanism is a name for a specific lifestyle that seeks refined sensual pleasure, although this stance does not follow logically from the philosophy. Epicurus warned explicitly against the pursuit of luxury. Indulgence would increase desires and make a person dependent on the whims of fortune.

Epicurus' thoughts about happiness are often reviewed from a philosophical standpoint (see for a good example Annas, 1993), but in this paper we ask the more practical question whether his advice for leading a happy life still deserves to be followed. To that end we will first present a description of Epicurus' life and his recommendations. Next we will compare his advice with the present day conditions for happiness as observed in modern empirical research. Note that we do not seek philosophical exegesis of Epicurus' ideas.

\section{Epicurus}

\subsection{His time}

Epicurus formulated his happiness advice during the Hellenistic period in Greek history that runs from 323 B.C., the year of the death of Alexander the Great until the establishment of the Roman Empire in 31 B.C. (Tarn, 1952). In this era many new philosophies were formulated and gained popularity; it seems that the philosophies in vogue at the end of the fourth century B.C., the schools of Plato and Aristotle, could no longer provide reasonable answers for life in the changing times that resulted from the politics and conquests of Alexander the Great. The new socalled Hellenistic philosophies, Stoicism, Skepticism and Epicureanism, are sometimes called the products of the new world Alexander the Great had made, and can be regarded as attempts to come to terms with the changing social and political circumstances (Long, 1986; Tarn, 1952). The Greeks came into contact with new philosophies, religions and cultures, and transplanted the social institutions of the Greek mainland to Asia and Egypt (Long, 1986). 
The sheer size of the Greek empire caused the importance of the city-state to decline. People were travelling around; citizenship was no longer bound to one city; and the city-state was no longer the way to organize society. The Greeks started to think about people as individuals living in a cosmopolitan universe of which Greece formed only a part (Jones, 1989). The old loyalty to the Greek race, the city-state, and its Olympic Gods didn't seem that important anymore. Commitment to civic and political activity could no longer compete with the more immediate claims of private life (Jones, 1989; Russell, 1990). The Greek citizens became alienated from the affairs of their own city.

The changes were accompanied by a general feeling of insignificance and insecurity. The world had become unpredictable and bewildering for many Greeks. The years after Alexander's death were characterized by political instability, wars and dynastic struggles (Russell, 1990; Tarn, 1952). This situation added to the impulse to turn away from the outer world and seek security and identity in the sphere of private relationships (Jones, 1989). The Hellenistic philosophies took various positions in an effort to deal with these changing times. Stoicism addressed the more highly educated and aristocratic citizens with its focus on public life. Epicurus' philosophy appealed mostly to the fearful and oppressed citizens, the ones that didn't want the new world (Tarn, 1952). It promised a way out of the turmoil into a more quiet and safe life.

\subsection{Personal history}

Epicurus was born on the island of Samos in 341 B.C. as the son of Neocles and Chairestrate. Because he was born in a colony of Athens he was an Athenian citizen and at the age of 18 he went to Athens to fulfil his military obligations. In 321 he joined his parents in Colophon on the west coast of Asia Minor. Then he stayed a while in Mytilene on Lesbos and in Lampsacus. The details of Epicurus' life in the period 320-310 are not well known, nor is it entirely clear where and by whom Epicurus was educated. He claimed to be self-taught, although tradition has it that he was schooled in the systems of Plato and Democritus (Laertius, 1994, pp. 3-4).

Between 307 and 305 Epicurus settled again in Athens. He purchased a house and a large walled Garden where he taught and where he and a group of followers formed a close community. His school became known by the name of the GardenKêpos. In antiquity the Garden was famous for its closed character, the enormous loyalty to Epicurus and the close friendships between the members. Epicurus stayed in Athens until he died in 271 at the age of 72. Although his writings were voluminous, there are only fragments left (Algra, 1998b, pp. 9-11).

After his death, Epicureanism continued to flourish as a philosophical movement. Communities of Epicureans sprang up throughout the Hellenistic world, a cult rose around the person Epicurus and celebrations were held in his memory. Epicureanism went into decline with the rise of Christianity and it was not until the Renaissance that serious interest in Epicureanism was revived.

\subsection{Philosophy}

Epicurus followed the popular division of philosophy into three parts: physics, logic and ethics. He confined logic to epistemology—kanônika-which enables us to distinguish true from false propositions. The primary criterion of truth comes from 
the senses; we can gain knowledge through the senses and we can trust the senses when properly used (Epicurus, 1994, p. 38). Feelings-pâthe-also provide criteria for the truth; they serve as criteria for values. Epicurus also identifies prolepsis as a criterion. The prolepsis of a thing is an instinctively acquired generic grasp of its nature and includes those of god, human beings and body.

Epicurus' physics is based on his epistemology: on the indisputable evidence from the sense-experiences and the natural generic conceptions. His physics is materialistic and mechanistic (Algra, 1998a, p. 26). He appropriated much of the mechanics of his predecessor, the atomist Democritus, but introduced an element of spontaneity. Epicurus believed that the basic constituents of the world were atoms moving in the void and that ordinary objects are conglomerations of these atoms. The properties of macroscopic bodies and all the events we see occurring can be explained in terms of the coalitions, rebounding, and entanglements of atoms (Epicurus, 1994, pp. 42-44).

Epicurus' thoughts about ethics are based on his view of physics and logic. In the domain of ethics we should trust our feelings of pleasure and pain. Pleasurehêdon $\hat{e}$ - is the only thing that is intrinsically valuable and should be regarded as the main criterion for all actions. It is given by human nature that all our actions aim at pleasure and try to avoid displeasure. Epicurus argues that the behaviour of the newborn confirms this theory (Epicurus, 1994, p. 128). Epicurus outlines the view that pleasure and pain are jointly exhaustive: the absence of pain is itself pleasure. This implies that there is no intermediate state: For we are in need of pleasure only when we are in pain and when we are not in pain then we no longer need pleasure. And this is why we say that pleasure is the starting point and goal of living happily. For we recognized this as our first innate good, and this is our starting point for every choice and avoidance and we come to this by judging every good by the criterion of feeling (Epicurus, 1994, pp. 128-129).

The freedom from pain, which is, as we have seen, in itself a pleasant state, consists in the lack of pain in the body-aponia-and the non-disturbance of the soul, a state Epicurus called the tranquillity of the mind-ataraxia-(Epicurus, 1994, p. 131). This state is also called static pleasure, because it is thought to arise from the stable atomic structure of our souls. The kinetic pleasures are thought to be less important, because they rely on the actual motion of the atoms and are temporary. This idea made Epicurus emphasize 'untroubledness' over the less important positive pleasures, although this static state could be achieved or varied by short-termkinetic-pleasures of stimulation. The kinetic pleasures have a bodily and a mental version. Mental pleasures can also consist in reliving past kinetic pleasures or anticipating future ones and can outweigh present pains.

Epicurus insists that one should trust one's feelings. This, however, does not imply that the accumulation of new instant pleasures increases happiness beyond what is achieved when all pain has gone (Epicurus, 1994, p. xviii). Thus the pursuit of luxury does not increase pleasure. What it can do is enlarge your desires, make you run the risk of becoming dependent on them and thus make you vulnerable to the whims of fortune. This implies that one sometimes has to pass up some pleasures in order to get a greater pleasure, and that many pains are better than some pleasures if a greater pleasure follows by enduring those pains (Epicurus, 1994, p. 129). To maximize pleasure one therefore has to calculate the relative roles of bodily and mental, static and kinetic pleasures. Epicurus was an 'unimpeachable ascetic who taught that 
"genuine pleasure" was not "the pleasure of profligates," but rather the simple satisfaction of a mind and body at peace' (McMahon, 2004, p. 11).

\section{Epicurus' advice}

Epicurus does not see the above-mentioned three parts of philosophy-logic, physics and ethics-as equally important. He subordinates logic to physics and physics to ethics. The purpose of knowledge is pragmatic and solely meant to free you from fears and mental uncertainty. Epicurus' philosophy aims at making life happy and promises happiness to anyone who embraces his viewpoint.

Let no one delay the study of philosophy while young nor become weary of it when old. For no one is either too young or too old for the health of the soul. He who says either that the time for philosophy had not yet come or that it has passed is like someone who says that the time for happiness has not yet come or that it has passed. Therefore both young and old must philosophise, the latter so that although old he may stay young in good things owing to gratitude for what has occurred, the former so that although young he too may be like an old man owing to his lack of fear or what is to come. Therefore, one must practise the things which produce happiness, since if that is present we have everything and if it is absent we do everything in order to have it. (Epicurus, 1994, p. 122).

\subsection{Four basic truths}

Epicurus' happiness philosophy is hedonistic in the sense that he equates the old Greek concept of happiness-eudaimonia-with pleasure-hêdone. Pleasure is the starting-point and the goal of living happily (Epicurus, 1994, p. 128). Life is pleasurable when the mind is free from fears and the body is content with natural satisfactions. You can achieve this state of happiness if you accept the four basic truths of Epicureanism, the so-called 'four-part cure' (Philodemus of Gardara, cited in Epicurus (1994, p. vii)):

1. Don't fear the gods

2. Don't worry about death

3. What is good is easy to get

4. What is terrible is easy to endure

\subsubsection{Don't fear the gods}

Epicurus claims that the gods exist because we have clear knowledge of them. ${ }^{1}$ They are happy and immortal, indestructible and blessed animals (Epicurus, 1994, p. 123). The gods are in a state of bliss, and are only occupied with the continuance of their own happiness. They do not have any needs, are invulnerable to any harm and do not concern themselves with the human world. The gods therefore have no influence over our lives and this is why we don't have to fear them.

\footnotetext{
${ }^{1}$ In Epicurus' view there is a natural conception (prolepsis) of god, a conception that is shared by all human beings.
} 
This leaves Epicurus and us with the question how there can be any order if the gods are unconcerned about human affairs. The physical reality lacks immanent order. It is up to us to find the limitations that human nature imposes on us and to create our own order. We have to make arrangements to manage the external threats as well as possible (Hutchinson, 1994, p. x). This means that there is no need to ask favours from the gods, because we humans are fully able to supply things for ourselves (Epicurus, 1994).

\subsubsection{Don't worry about death}

Get used to believing that death is nothing to us since 'all good and bad consists in sense-experience and death is the privation of sense-experience' (Epicurus, 1994, p. 124). When you die, your soul ceases to exist, because it is composed of very fine and smooth atoms that are dispersed if the body no longer holds them together, says Epicurus in his Letter to Herodotus (Epicurus, 1994, p. 65). Therefore, when you are dead you cannot deal with death and when you are alive you don't have to worry about death either since death is not yet present. There is no life after death, as Epicurus puts it: '...it [death] is relevant neither to the living nor to the dead, since it does not affect the former, and the latter do not exist' (Epicurus, 1994, p. 125). Epicurus chooses a rational solution to eliminate our fear of death, which is in his eyes a great source of unhappiness.

\subsubsection{What is good is easy to get}

As we have seen above, Epicurus states that what is pleasurable is easy to get; it is not difficult to achieve the state of absence of pain. Epicurus seems to have been occupied by the fact that a lot of people are unhappy, despite the fact that their means of living could be sufficient for a pleasurable life. The goal of his philosophy is to carefully manage pleasures, for it is the specific way in which people try to fulfil their needs where they go wrong (Annas, 1993, p. 199). According to Epicurus, our desires fall into three categories: '...some are natural and necessary, some natural and not necessary and some neither natural nor necessary but occurring as the result of groundless opinion' (Epicurus, 1994, p. xxix).

Natural and necessary desires will liberate us from pain when they are fulfilled. We cannot be happy, healthy or even alive without these desires being fulfilled. Epicurus mentions food, water, shelter from the elements and safety from the animals and people. According to Epicurus it is easy to provide for the fulfilment of these basic needs yourself.

The natural desires that do not cause pain when they remain unfulfilled are not necessary. An example is delicious and expensive food. This is pleasurable, but does not remove pain better than ordinary food. Therefore it is natural but not necessary. The natural and necessary desires are generic; it is the desire for food, for drink and so on. The unnecessary and natural desires are the preferences for specific kinds of food, such as lobster. You need to fulfil natural and necessary desires, but you can only want specific unnecessary and natural desires, and it is better not to become dependent on the latter, for that would increase the risk of unhappiness (Annas, 1993, p. 193). Epicurus stresses that we will be happy if we stick to the natural and necessary desires, 'not in order that we might make do with few things under all 
circumstances, but so that if we do not have a lot we can make do with few, being genuinely convinced that those who least need extravagance enjoy it most' (Epicurus, 1994, p. 130).

Unnatural and unnecessary desires are, for example, the thirst for honours and the desire for crowns and statues. These desires limit the self-sufficiency of people and increase the risk of unhappiness. It is better not to pursue these desires since they will cause uncontrollable desires and moreover, the pleasures that come from the fulfilment of unnecessary or unnatural desires, can give rise to troubles many times greater than the pleasures. Becoming accustomed to simple ways of life makes us completely healthy, makes us unhesitant in the face of life's necessary duties, puts us in better condition for the times of extravagance which sometimes come along and make us fearless in the face of chance (Epicurus, 1994, p. 131).

\subsubsection{What is terrible is easy to endure}

Good is what gives us pleasure; bad is what causes us pain. According to Epicurus these pains are always easy to ignore, since heavy pains don't last very long and chronic pains cause only mild distress (Epicurus, 1994, p. 4). This implies that under all circumstances we can try to push back pains and other discomforts by focusing on the opposite feelings of pleasure. Bodily discomfort can be outweighed by the mental pleasure of reliving past kinetic pleasures and anticipating future ones.

\subsection{More advice}

The good, happy and pleasurable life Epicurus promises us when we will follow his advice cannot be achieved without the study of philosophy. He also identifies some virtues that contribute to our happiness, among which prudence is the most important. He indicates friendship and justice as two important features that provide us security which he identifies as a natural good (Epicurus, 1994, p. vii).

\subsubsection{Philosophy}

Philosophy should not be pursued as knowledge for its own sake, but to bring about peace of mind and body. Philosophy helps us to eliminate the two main sources of fear that affects our feelings of happiness negatively, our fear of death and our fear of the gods. Besides that, Epicurus finds, as probably most philosophers do, the activity of philosophy itself pleasurable as he puts it: '...in philosophy the pleasure accompanies the knowledge. For the enjoyment does not come after the learning but the learning and the enjoyment are simultaneous' (Epicurus, 1994, p. 27).

\subsubsection{Prudence}

Epicurus' ethics is hedonistic. As Epicurus puts it: 'One must honour the noble, and the virtues and things like that, if they produce pleasure. But if they do not, one must bid them goodbye' (Epicurus, 1994, p. 132). Virtues that do not lead to pleasure only provide empty, pointless and disturbing expectations of rewards. But, as he puts it in his Letter to Menoeceus, most virtues are natural adjuncts of the pleasant life and the pleasant life is inseparable from them. Since we have to search out the reasons of 
every choice and to get rid of the opinions that are the sources of the greatest turmoil in men's souls, we also have to be prudent beings (Epicurus, 1994, p. 132). Therefore, Epicurus finds prudence the most important of all virtues; without this virtue we will not be able to decide what contributes most to our pleasure. He also considers prudence the source of all other virtues, 'teaching that it is impossible to live pleasantly without living prudently, honourably, and justly and impossible to live prudently, honourably, and justly without living pleasantly' (Epicurus, 1994, p. 132).

We need prudence to be able to make deliberated decisions about which pleasures to choose or to avoid, and it is also the best weapon to fight fate, chance and misfortune (Epicurus, 1994, pp. 129-130). The wise man knows that nothing, good or bad with respect to living blessedly is given by chance to men. The prudent man therefore recognizes that 'misfortunes must be cured by a sense of gratitude for what has been and the knowledge that what is past cannot be undone' (Epicurus, 1994, p. 134). It also leads Epicurus to say that 'one should envy no-one. For the good are not worthy of envy, and the more good fortune the wicked have, the more they spoil it for themselves' (Epicurus, 1994, p. 53).

\subsubsection{Security}

In order to live an undisturbed life, Epicurus believes that we have to be safe from our neighbours. This security is most easily provided through friendship, but also by making laws or social contracts 'about neither harming one another nor be harmed', and by withdrawal from the people since 'the purest security is that which comes from a quiet life and withdrawal from the many' (Epicurus, 1994, p. xxxi).

The laws exist for the sake of the wise-the ones who follow Epicurus' teachings-not because they would commit injustice, but because they will not suffer injustice (Clement of Alexandria and Stobaeus, cited in Epicurus, p. 103, 104). Epicurus views justice in a hedonistic way: it should aim at our own pleasure. His argument for obeying the law has the same signature; breaking the law will cause disturbance since we will live with the fear of being discovered by our neighbours (Epicurus, 1994, p. 70).

Although the fruit of justice is great, Epicurus doesn't encourage people to be active in public life, in business or politics or to interfere with legislation. Such actions can bring power, but that doesn't always bring the personal security from others we hope to find in it. Moreover a public life puts one at a great risk for disturbance. As Epicurus puts it: 'The presence of wealth, honour and admiration among the many will not produce joy or dissolve the disturbance of the soul' (Epicurus, 1994, p. 53). Living a quiet life among like-minded friends will more likely lead to the happy life. Public life is only a prison (Epicurus, 1994, p. 58).

\subsubsection{Friendship}

Friendship is of the greatest importance; it provides us with personal security. In Epicurus' hedonistic view, every friendship takes its origin from the benefits it confers on us. Friends provide each other with support and assistance. Safety is impossible without friends. Even the most self-sufficient man sometimes needs someone to take care of him. But Epicurus also states that friendship is worth choosing for its own sake (Epicurus, 1994, p. 23). Friendship is intrinsically valuable. 'Of the things which wisdom provides for the blessedness of one's whole life, by far

Springer 
the greatest is the possession of friendship' (Epicurus, 1994, p. xxvii). Although friendship has a hedonistic starting-point, in the maturation of the friendship a friend is no longer considered to be a means to our own happiness, but the friend has become part of our own life, a part of our selves. We no longer only strive for our own pleasure, we'll also seek pleasure for our friends, and it has become a mutual project. Epicurus takes this position to extremes: 'The wise man feels no more pain when he is tortured than when his friend is tortured, and will die on his behalf; for if he betrays his friend, his entire life will be confounded and utterly upset because of a lack of confidence' (Epicurus, 1994, pp. 56-57).

Epicurus considers friendship the most important aspect in social life, while he does not regard sexual relationships equally important. He says that sex hasn't done anyone good, and you can consider yourself lucky if intercourse does not cause any harm (Laertius, cited in Epicurus 1994, p. 43). ${ }^{2}$

Epicurus attitude towards marriage is a subject of controversy (Brennan, 1996; Chilton, 1960), but in general it is agreed that he preferred people not to marry, because in marriage, as Rist (1980, pp. 127-128) put it, 'we leave ourselves open to troubles and inconveniences which may arise from wives and children we could otherwise avoid. So the wise man does not marry and have children'.

Risk avoidance may have been the driving force for this attitude. Marriage and family life implies a strong dependence on a very limited number of individuals and loosing these bonds would inflict serious pain. Larger and more diffused forms of community, such as in the Garden, are less dangerous. The reasoning behind this position parallels that on food, and the dislike of dependence on specific (unnecessary) satisfiers (Annas, 1993, p. 197). This character of Epicurus' philosophy seems apparent when he states that his followers should not mourn a friend who dies before they do, as if there was need for pity.

Note however that our interpretation is not consistent with the extreme loyalty that Epicurus asks from good friends (Rist, 1980, p. 128). A second point to remember is that the modern institution of marriage between two equal partners has a lot in common with the friendship Epicurus idealized.

\section{Reception}

In the course of history the critics of Epicureanism have been representing Epicurus' philosophy as a lazy-minded, shallow, pleasure-loving, immoral or godless travesty of real philosophy (Hutchinson, 1994). His dismissal of the non-hedonistic virtues, his retreat from politics and the idea that our soul disperses when we die, gave rise to opposition by Christians, academic philosophers and political authorities and to the distortion of his message. The fact that Epicurus lived and taught in a closed community, the Garden in which he was honoured as a god and in which also slaves and women were welcomed, didn't contribute to a clear understanding of his philosophy either: outsiders could only guess what was going on inside and this led to many speculations. The presence of hetaerae led to rumours and provided opponents of Epicurus' school with an excuse to paint the Garden as a school for scandal and orgies (Jones, 1989, p. 19). Today the word 'Epicureanism' has even come to mean a

\footnotetext{
${ }^{2}$ Some suggest that Epicurus' negative opinion about sex is caused by an error in translation, see Brennan (1996) for a discussion.
} 
life stance that implies the pursuit of sensual pleasures, a pretentious enthusiasm for rare and expensive food and drink.

Although many of Epicurus' contemporaries were very critical towards his happiness advice, his advice on how to live a happy life must have made sense to the people living in Hellenistic times; Epicurean communities sprang up all over the Mediterranean world and students hardly ever left the commune for other philosophical systems (Hutchinson, 1994). For many it was a workable way to come to terms with the changing and changed world they lived in. We can also be quite confident that his philosophy worked for Epicurus himself. As he wrote on his dying day:

'I write this to you while experiencing a blessedly happy day, and at the same time the last day of my life. Urinary blockages and dysenteric discomforts afflict me, which could not be surpassed for their intensity. But against all these things are ranged the joy in my soul produced by the recollection of the discussions we have had' (Laertius, cited in Epicurus 1994, p.79)

He died in a way that was consistent to his teachings about tolerance to disease, peacefully and cheerfully (Bitsori \& Galanakis, 2004).

\section{Applicability of the advice today}

Epicurus' advice for leading a happy life was tailored to the situation of his time. Are his recommendations still of use today? Below we will try to answer that question by comparing Epicurus' counsel with conditions for happiness observed in present day society. For that purpose we use the large body of empirical research on life satisfaction in western nations in the second half of the 20th century and inspect how well these data fit Epicurus' recommendations for a happy life. Epicurus' concept of happiness is compatible with the definition of happiness that is used in empirical studies, that is, 'subjective enjoyment of life-as-a-whole'.

\subsection{Back away from society?}

Epicurus tried to shelter his followers from the Hellenistic world of his times in which the old securities were gone. He started a mini-society-the Garden-and many of his followers lived in similar communes. The organization of the Garden was hierarchical and Epicurus was the only one who was awarded the title 'wise man'. He strove to create a secure and comfortable atmosphere through friendship. The association between members of the Garden was freer than was usual in other schools, and members did not have to give up their private properties (Jones, 1989, pp. 20-21). Epicurus recognized that happiness is enhanced in social conditions that provide security and allow most autonomy/freedom (Veenhoven, 2002, p. 21).

Although living in the Garden provided a relatively safe, protected life with a full stomach, it is another thing to say that isolating yourself in such a commune is a wise idea. Living in a hierarchical community limits the freedom of choice for its members, for important choices in life are already taken on the basis of the philosophical doctrine of the commune. An example is that active political involvement in the outside world is strongly discouraged. The commune therefore does not encourage the members to make their own choices in life, which appears to be crucial aspects of 
the multiple-choice societies that enhance happiness (Veenhoven, 1999). To follow a path in life that is prescribed by a leader of a commune, implies that the individual members do not give an autonomous evaluation of all aspects of their own living conditions. Instead, the commune makes important choices for them to assure harmony within the commune. If all individuals would think for themselves and pursue their own ideas of happiness, heterogeneity, disagreement and conflict would result and the concept of the ideal, hierarchical community is threatened. This is what Crombag and Van Dun (1997) call an 'utopic paradox'. Happiness is the positive evaluation of one's life as a whole, but living in a commune makes it impossible to make this evaluation autonomous. The members cannot decide for themselves what is best for them. One problem with this position is that it did not allow Epicurus to pay proper attention to personality differences. For example, it is easy to imagine that somebody high on sensation-seeking who likes to live on the edge will not be happy with the tranquility that Epicurus envisioned in his Garden. So living conditions in the Garden may have been favourable and Epicurus an enlightened ruler, but the resulting happiness of the members lacked an essential ingredient: the individualistic evaluation of living conditions and the freedom of choice that is based on these individual preferences.

\subsubsection{Avoid public life}

Epicurus felt that politics and public life only involve needless mental stress and should be avoided. Participation in the social life of the Garden was a substitute for involvement in society at large. The consequence was that people became more dependent on community life. With modern data in mind we must conclude that Epicurus' philosophy regarding one's position in society, limited the options for his followers in an unwarranted way. To be engaged in public life will certainly cause some problems, but the net effect on happiness appears to be positive. In present day society at least, we see a strong correlation between happiness and social involvement. ${ }^{3}$ Happiness is typically higher among employed people (WDH section E 2), among people who go out often (WDH section L 3) and among members of voluntary associations (WDH section S 7). The withdrawal from the many is not the optimal choice for the majority of people.

\subsubsection{Renounce fame and wealth}

The desire for fame, status and wealth is unnecessary and unnatural according to Epicurus. He stated that you had to free yourself from the prison of general education and politics (Epicurus, 1994, p. 58). The findings gathered in the WDH show that happiness correlates positively with social rank (WDH section S 9), education (WDH section E 2), occupation (WDH section O 1), and social participation (WDH sections S 6-8). Again, Epicurus' concern with avoiding sources of possible pain leads him to reject an important source of happiness.

An interesting aspect is Epicurus' position on income. Epicurus is right for modern readers that income (I 9) does not contribute much to happiness (Epicurus,

\footnotetext{
${ }^{3}$ Since research is abundant, we will not cite all the studies separately. Instead, we will note the section on correlational findings in the World Database of Happiness (WDH) where these data can be found (Veenhoven, 2006).
} 
1994, p. 67), and modern people value happiness far above wealth (Diener, Suh, Lucas, \& Smith, 1999). But it is questionable if Epicurus was also right for his contemporaries. Income is a powerful predictor of happiness in developing countries (Veenhoven, 2002). One can only speculate about the significance of income in classical Greece, but it would not be a great surprise if more income would be of importance in those days in which economic development was not comparable to that of modern industrial nations.

\subsection{Focus on friends}

Not only the quality of society matters; also the position one has in a society is of influence on happiness. Intimate personal relationships with a partner and friends are strongly correlated with happiness (e.g. Headey \& Wearing, 1992). The many findings on these matters are gathered in the WDH, sections M 1-4 (marriage), F 1-3 (family), F 6 (friends). Epicurus recognized how important personal relations are. He valued affective relationships very much, and in particular friendships.

'Friendship dances around the world announcing to all of us that we must wake up to blessedness' (Epicurus, 1994, p. 52).

Epicurus valued friendship above marital relationship. Note, however, that Epicurus may have had a higher opinion of marriage as it is in the modern age, because partner relationships nowadays are more often based on the friendship between equals.

The existing data suggest that marriage is more important than friendship for modern readers. The correlations between happiness and being married (M 2) tend to be stronger than the correlations between happiness and contacts with friends ( $F$ 6). Likewise, married women without a close friend were found to be happier than unmarried people with a close friend (Ventegodt, 1996, p. 170). One can conclude that Epicurus may have placed too much emphasis on generic friendship and at the expense of specific marital ties.

The data indicate that happiness is served by specificity in social bonding. Kamp Dush and Amato (2005) describe in a large sample of Americans under the age of 55 , that on average married people are happier than cohabiting people, cohabiting people are happier than the ones that are steady dating, steady dating people are happier than multiple daters, and the multiple daters are happier than the nondaters. However, this does not mean that Epicurus is not right. His point is that the disadvantages of marriage are greater than the satisfactions. In modern terms this implies that it is too risky to be dependent on specific desires (a spouse), because of the pain that marital conflict, divorce or widowhood would bring. We have already seen that the married are happier than unmarried, so they can live with average marital conflict, but we should also weigh the yields of marriage against the costs of divorce and widowhood. We will do that in a paragraph below.

\subsection{Healthy living}

Epicurus regarded health of the body as one of the most important determinants of happiness, but he placed even more emphasis on the health of the soul. When the mind is free of disturbance then the pains of the body are endurable, and do not have 
to affect our happiness. We can learn to push back pains and discomfort through mental pleasures.

Epicurus' remarks about this subject fit modern findings on the relationship between happiness and health. Health is strongly related to happiness, in particular self-rated health. 'The impact of health on happiness depends for a great part on the individual's perception of the situation' (Diener et al., 1999, p. 287). This links up with the finding that happiness is more strongly related to mental health than to physical health (WDH Sections M 7 and P 6). Or, as Epicurus would have put it, a mind free of disturbance would not only enhance physical health, but would also help to deal with the hardships of sickness. We can still be happy when our physical condition is not good.

\subsection{A detached stance to life}

The above-mentioned findings give an impression of the strengths and the weaknesses for present day conditions of Epicurus' advice. Still, it can be argued that this is not the essential part of his happiness advice. His central idea is that one should not seek happiness in specific living conditions, but that one should be able to achieve happiness regardless of external conditions. He stimulates internal coping. To evaluate this position, we will consider it in the light of modern psychology.

Happiness is the Chief Good in Epicurus' philosophy, but it is important to note that he does not value positive affect all that much. Happiness is conceived as absence of pain, but even the pain is not that important, because he states that the severest pains are easy to endure. Epicurus' hedonism has strong stoic or ascetic tendencies. Parducci (1995, pp. 17-18) comments: Epicurus' 'position was to establish an ascetic detachment from material conditions so as to minimize the pain of their loss. Although Epicurus claimed that a man could be happy even in a rack, it is not clear that he believed genuine happiness to be possible'.

The position of Epicurus is difficult to judge, because of the seeming inconsistency of his remarks that pleasure is the same as the absence of pain and the idea that pain is easy to bear. Our interpretation is that Epicurus placed pleasure and pain on a continuum and that a person can experience either positive or negative affect. However he also recognized that people reflect on their affective experience and that this meta-appraisal can make a difference. This interpretation makes it possible to highlight several strengths and weaknesses of his happiness advice.

Epicurus was probably wrong with his idea about the continuum of positive and negative affect. Pleasure and pain are registered independently from each other in our brains (e.g. Cacioppo \& Gardner, 1999). Pain relief and the escape from expected pain leads to positive affect (e.g. Frijda, 1988; Lazarus, 1991), but continuous absence of pain does not necessarily lead to happy tranquillity, but can also be boring. Headey and Wearing (1992) describe the fact that a significant minority of people have low levels of psychological distress and are unhappy at the same time. Csikszentmihaly (1999) states that happiness results from optimal functioning that can be found between boredom and anxiety. These findings contradict Epicurus' notion of happiness as mere absence of pain. Epicurus' happiness advice does not cater for exhilarating aspects of a business man's life that involves risks and losses but also makes one live to the full and be happy on balance. He also did not think of anhedonia, the inability to experience emotion, that is characteristic of people with a depressive disorder. This condition is often more 
difficult to bear than emotional pain itself. Happiness is definitely something other than the mere absence of all pain (Bergsma, 1995).

Headey and Wearing (1992, pp. 4-8) also notice that some people are happy despite the fact that they experience high levels of psychological distress. People often perceive life as both quite satisfying and quite stressful. This goes against Epicurus' idea that happiness can be equated with absence of pain. Still, the combination of high distress with happiness can be reconciled with Epicurus' philosophy, because of his idea that we can learn to tolerate pain.

The independence of positive and negative affect has two consequences for Epicurus' position. His notion that avoiding pain is sufficient for establishing a good quality of life may be too conservative. The second consequence is that he neglected the role of positive affect. We start with a discussion of his ideas to avoid pain.

\subsection{Avoid pain and greed}

Epicurus' idea that we should not want too much is a consequence of his tendency to avoid the risk of pain. Strong desires can make us miserable if we have to live without the objects of our desires. Epicurus' idea not to indulge seems to be fruitful. Csikszentmihaly (1999) praises Epicurus because his philosophy encourages people to defer gratifications. Epicurus claimed that all pain was evil, but that we should not avoid pain, when this saves us more pain in the long run. The same is true for pleasures. All pleasures are good, but we should not indulge if the pleasures harm us in the long run.

Moderation in pleasures turns out to be successful in terms of happiness. Headey and Wearing (1992, pp. 92-93) show that such a pleasure-hunting lifestyle fails in the long run. The purely hedonistic way of life often means that people fail to maintain intimate relationships, whereas such relationships form a great source of happiness.

The question is whether Epicurus emphasized deferring gratifications too much. He favoured a serene life with the motto: "If a little is not enough for you, nothing is." There are three ways to evaluate this position. The first is a discussion of the limits of willpower, the second focuses on the optimal level of openness to pleasurable experiences and the third is a discussion of the merits of modest aspirations. We start with willpower.

\subsubsection{Can we restrain?}

Self-regulation can be thought of as the internal resource that is used by the self to make decisions, respond actively, and exert self-control. Epicurus' philosophy of the good life requires that one should not spontaneously indulge in pleasures, but always ask what the consequences are in the long run. If I will enjoy this excellent food, how big is the danger that I will get frustrated if I would have to do without it later? Following Epicurus seems to require a lot of self-regulation and it has become clear that willpower is a limited resource (e.g. Schmeichel \& Baumeister, 2004).

\subsubsection{How much enjoyment is too much?}

This theoretical point can be explained by results from happiness research. Hedonism is the way of life in which pleasure plays an important role, and as we noted above, it is possible to take this position to the extreme. A drug addict whose life 
deteriorates in the hunt for another pleasurable shot can serve as an example in this respect. But does this mean that we should curtail our pleasures to the limit that is necessary for our survival? The question has not had a lot of attention in research, but Veenhoven (2003) presents data that suggest that a 'heavy dose of pleasure' does not limit happiness or longevity in the long run. Having sex frequently and valuing free time show a linear positive correlation with happiness, and the use of stimulants an inverted U-curve. Peterson, Park, and Seligman (2005) describe the fact that an orientation toward pleasure makes a (small) contribution to well-being, without harming the quest for meaning or engagement in life.

Perhaps these results indicate that we should use our resources for self-regulation especially if it comes to big issues in life, and we should not value pleasure over finding meaning and engagement. We waste our resources by focussing on minor points like limiting innocent pleasures.

\subsubsection{Can we want too much?}

Epicurus claims that high aspirations are a threat to happiness, because of the risk of 'unnecessary' frustration. Several modern psychologists agree, and lowering aspirations and expectations is a part of the program that Fordyce (1977, 1983) has developed to increase personal happiness. Yet empirical studies do not show that happy people want less than the unhappy. To the contrary, happy people set typically higher aspirations and expect more positive outcomes (WDH section L 7). This has several reasons: one is that wants keep us going and that fully functioning makes us feel happy. Wanting nothing often means doing nothing. Another reason is that happiness works as a go-signal and stimulates us to reach out and achieve things (Fredrickson, 1998, 2001).

\subsection{The role of positive affect}

Though there is certainly a point in moderation, Epicurus has overstated that case. Possibly he did so in his role as a teacher. Exaggerating the dangers of hedonism may be the best way to counter possible side effects. But the idea that Epicurus made a mistake for educational purposes does not seem to be the whole story. The way Epicurus thought about happiness as the opposite of pain, made him think too easily about positive affect. It was something that would happen to you more or less automatically if you were in the right frame of mind. He cognitively explained away the fears for the gods and death and added: 'what is good is easy to get.' This is why Epicurus advises readers to be too passive in their pursuit of happiness. Annas (1993, p. 198) puts it like this: 'Epicurean happiness is bought at the price of adjusting the agent too thoroughly to the world, that is too passive a conception of human life.' In contemporary life data suggest that happiness is better served with active involvement in society. We not only want a mind that is free of disturbance, but we also have the possibility to try to control the interaction with the environment so that we can change our (view of the) world so that it better suits our preferences.

Fredrickson's $(1998,2001)$ 'broaden-and-build' theory of positive affect gives a theoretical underpinning of this idea. Her first key position is that positive affect broadens the individual's momentary mindset, and she urges one to play, explore and to integrate in social networks. These activities build the resources of the individual for they lead to the discovery of novel and creative ideas and stronger social bonds. 
The importance of positive affect is underlined in several empirical studies and analyse. Positive affect stimulates health and longevity (Danner,Snowdon,\& Friesen, 2001; Pressman \& Cohen, 2005), finding meaning in life (King, Hicks, Krull, \& Del Gaiso, 2006), taking advantage of unforeseen opportunities (Carver, 2003) and also leads to success. Positive affect promotes sociability and activity, altruism, liking of self and others, effective conflict resolution skills and perhaps original thinking (Lyubomirsky, King, \& Diener, 2005). It is a serious omission that Epicurus neglects the constructive aspects of positive affect. Happiness is better served by a full life with pleasure, meaning and engagement (Peterson et al., 2005), than with an empty life that focuses primarily on avoiding pain.

\subsection{Acquiescence}

There is one aspect of the 'four basic truths' that escapes the analysis in the paragraphs above. The statement that 'what is terrible is easy to endure' adds a dimension to Epicurus philosophy, that fits in with the spiritual tradition that places greater emphasis not on an emotional high, but on a state of peace, tranquillity and understanding (Brown \& Ryan, 2003). Epicurus four-part cure has three remarks on coping with pain (fear of Gods, death and terrible pain) and all three boil down to the idea that it is not necessary to lose emotional equilibrium over these stressors. Above we have noted that Epicurus does not stimulate people enough to actively pursue happiness, but it is another matter when he offers wisdom in dealing with hardships.

The first thing to notice is that Epicurus' advice focuses on the hardest parts of existence. Death, disease, terrible pain, the impossibility of changing the past and ill fate (the gods) are mentioned explicitly. These stressors have in common that they are unchangeable. Efforts to change the event itself will only yield frustration and desperation. Persons have to find a way to cope with this difficult psychological content. The direct approach to this is to try to change the frequency or intensity of these difficult thoughts and feelings. There are certainly occasions where this works. Abbe, Tkach, and Lyubomirsky (2003) claim that dispositionally happy persons use distraction successfully in dealing with problems. But sometimes the attempts to escape make things worse. For example, avoidance seems to be at the heart of several forms of anxiety and post-traumatic stress disorders (Abueg, Follette, \& Ruzek, 2001). The efforts to change one's negative feelings can make them stronger (Segal, Williams, \& Teasdale, 2002).

\subsubsection{Coping with pain}

How can we tell the difference between emotion regulation processes that reduce or increase the impact of negative experiences? There have been several attempts to understand this difference (e.g. Gross, 1998a, b). A useful distinction in this respect is the difference between suppression of negative emotional content and reappraisal of the situation. The first tactic increases negative emotion and decreases happiness. Reappraisal has the opposite results (Gross \& John, 2003). Epicurus makes the right choice between the two. He reappraises fear of the gods and fear of death in a way as to suggest that they are no longer relevant for our emotional well-being, but he does not suppress these fears for he lets them take the centre stage in his philosophy. 
Another question is if Epicurus' reappraisals are strong enough to make a meaningful difference for emotional reactions.

The idea that pain is easy to endure cannot simply be classified as a form of suppression or reappraisal. It is a second-order change, a change on the meta level (Hayes, 2001). The central idea behind Epicurus' remarks seems to be that people can allow themselves to feel the pain for it is quite possible to endure it without being too much disturbed by it. This interpretation requires some goodwill and reading between the lines, but if it is correct, then it is reasonable to expect that reading Epicurus can make it easier to deal with the pain. Calm acceptance of mental content, as is encouraged by diverse schools of thought behind Buddhism, psychoanalytic free association and systematic desensitization, seems to be a helpful thing to do. Empirical evidence suggests that it helps in dealing with a wide range of psychological disorders (Hayes, Folette, \& Linehan, 2004), physical pain and a variety of well-being outcomes (Kabat-Zinn, 2000). One of the positive aspects of acceptance is that it helps with the experience of negative psychological content, without a need to act or ruminate if the situation is unchangeable. This makes it possible to deal with hardship without making things worse by avoidance, negative thoughts about the self or counterproductive action. For example, accepting that you feel bad because you crave for alcohol, can actually prevent relapse to binge drinking. The paradox is that people can regain control over their lives if they discontinue their efforts to get a better grip.

\subsubsection{Mindfulness}

If we take this reasoning one step further, we can link the concept of 'enduring pain' also with well-being outside the realm of clinical populations. Brown and Ryan (2003) investigated the effects of mindfulness, a concept that is closely related to acquiescence, but adds the dimensions of willingly taking in positive and negative psychological content. Mindfulness requires a more active and alert attitude than mere acceptance. Ryan and Brown (2003, p. 822) quote two different descriptions of mindfulness: 'the clear and single-minded awareness of what actually happens to us and in us at successive moments of perception' and 'keepings one's consciousness alive to the present reality'.

Being mindful correlates positively with life satisfaction, vitality, autonomy, competence and positive affect and negatively with negative affect, reported physical symptoms, depression, anxiety and impulsiveness. Experimental manipulation to enhance mindfulness also yielded positive results (Brown \& Ryan, 2003).

Mindfulness skills are gaining attention from psychotherapists, because they can be of help for clients who have to overcome adversity. The Journal Clinical Psychology: Science and Practice devoted a special issue to mindfulness in 2003. Bear (2003) states:

The empirical literature on the effects of mindfulness training contains many methodological weaknesses, but it suggests that mindfulness interventions may lead to reductions in a variety of problematic conditions, including pain, stress, anxiety, depressive relapse, and disordered eating.

Mindfulness can be a positive factor in life and Epicurus seemed to have realized this in his ideas about enduring pain and living deliberately and prudently, without the need to act on the feelings of the moment. Epicurus' philosophy is worthwhile in dealing with hardship and pain, although it requires some active interpretation of 
his texts to use them constructively. Paradoxically, Epicurus underestimated the tolerance people have for minor pains, for he advised them to shy away from involvement in society as a means of pain reduction, ignoring the fact that the positive experiences linked with involvement can offer enough compensation for the hassles.

The combination of acceptance with passivity and moderation in the hunt for pleasurable experiences also implies a danger. Scheier, Carver, and Bridges (2001) suggest that the line between stoic resignation and acceptance is not always clear and that the resignation has adverse consequences. Acceptance seems to be a healthy alternative, if it brings somebody to abandon goals that are no longer within reach and to engage in the pursuit of alternative goals that still are possible. If somebody with a deadly disease abandons all hope and accepts the inevitable, this seems to shorten the lifespan. A healthier alternative is if one decides what can still be done with the time left, for example spend more time with family. Acceptance is harmful when it implies stoic 'goallessness'.

\section{Does refraining from marriage pay off?}

\subsection{An empirical test}

Annas (1993) describes Epicurus' philosophy as being risk aversive. It is better to avoid pain than to indulge in pleasures. In the paragraphs above we concluded on the basis of a mixture of theoretical and empirical arguments that this position is too strict. Still this exercise is not completely convincing from an Epicurean point of view, for the philosopher does not argue that plain bread is just as tasty as lobster, but that the preference for lobster causes problems if one becomes dependent on it, in that life might take such a turn that a person has to live without it. In a similar vein, he argues that marriage may involve pleasures, but that these are not sufficient to compensate for the inconveniences. For a modern reader the inconveniences would translate as marital conflict, divorce or widowhood. In other words, it is in Epicurus' view that the lifetime benefits of marriage do not weight up against its costs and one can better abstain from marriage. In this section we will check whether this claim applies today. It is established that married people are typically happier than the unmarried ${ }^{4}$ but that among the unmarried the never married are happier than previously married but divorced or widowed people (e.g. Glenn \& Weaver, 1988; Peters \& Liefbroer, 1997; Waite, 1995). Clark and Oswald (2002) translated the experience of life-events relating to partnerships into a monetary 'compensation amount'. In their calculation, marriage has a happiness value of $£ 70.000$ a year, and widowhood could be compensated with a monetary sum of $£ 170,000$ a year. In other words, you have to stay married for 3 years to compensate for 1 year of widowhood. Evidently, those figures are biased because they are derived from reactions to life changes, and it is known that people have amazing ability to adjust to adverse circumstances and that happiness tends to return to baseline level in time (e.g. Headey \& Wearing, 1992; Suh, Diener, \& Fujita, 1996).

Following Epicurus warnings we should consider the number of years that people spend in each type of marital status. If people who marry are likely to spend a long

\footnotetext{
${ }^{4}$ We use the term 'married' for all people living together in a relationship with a partner. 
period of life divorced or widowed, this could have a substantial effect on their overall happiness. In order to evaluate this issue we use the concept of 'happy life years' (HLY), as introduced by Veenhoven (1996). This concept is defined as the number of happy years a person is expected to live. It is calculated by multiplying the number of years a person is expected to live by a happiness weight factor for each of these years. This weight factor will vary with the marital status. Mathematically, this could be expressed as

$$
\mathrm{HLY}=\sum \mathrm{Y}_{\mathrm{p}} * \mathrm{H}_{\mathrm{p}}
$$

where HLY is the number of Happy Life Years, $\mathrm{P}$ is a vector of possible states that a person can occupy, $\mathrm{Y}_{\mathrm{p}}$ is the number of years a person lives in state $\mathrm{P}$, and $\mathrm{H}_{\mathrm{p}}$ is the happiness weight factor attached to state $\mathrm{P}$.

\subsection{Method}

In order to estimate the number of HLY over the life time, decisions have to be taken on (a) the number of positions $P$ that should be distinguished, (b) the number of years people spend in each of these positions, and (c) the calculation of the happiness weights that are attached to each of the positions. We will discuss each of these three issues in turn.

Most research on the relationship between happiness and marital status compares the happiness of married people with those of the never married, divorced and widowed. This does not take into account the increasing complexity of partner relationships. As a result of the increasing popularity of unmarried cohabitation, living apart together, divorce, and remarriage, people often occupy a diversity of positions during their life course. Since we are not able to take all this potential complexity into account, we make a distinction between five possible marital statuses: (a) never married, (b) first marriage, (c) divorced or separated, (d) remarried (e) widowed. We do not differentiate formal and informal marriage. The latter phenomenon has gained popularity in many Western countries during the last few decades and the relation with happiness is similar (Peters \& Liefbroer, 1997). The second thing to notice is that we make a distinction between people in their first 'marriage' and people in their 'second marriage'. This is done because well-being in a second marriage is often lower than in a first marriage (Kurdek, 1990; Peters \& Liefbroer, 1997). The next question is then what part of their lives people spend in each of these five states. In our opinion, it does not make sense to calculate this for the 'average' person. Rather, one would want to describe different marital careers. In Table 1, we present six common marital careers in present day Dutch society. The

Table 1 Overview of different types of life courses

\begin{tabular}{ll}
\hline Type & Sequence of events \\
\hline I & Never married-death \\
II & Married-death \\
III & Married-widowhood-death \\
IV & Married-divorce-death \\
V & Married-divorce-remarriage-death \\
VI & Married-divorce-remarriage-widowhood-death \\
\hline
\end{tabular}


first life course type is that of the never married and exemplifies the advice of Epicurus to shun marriage. Life course types II and III are typical for people who marry and do not divorce. For half of the partners these unions will be dissolved by the death of the spouse. Life course types IV, V, and VI exemplify the varied experiences of people who experience divorce or separation. Some will not remarry (type IV), some will remarry and live with their new partner until death (type V) and some will remarry and experience the death of their second spouse (type VI). Evidently, some life courses will be more complicated than the six we have outlined here. However, these will only constitute a very small minority of all life courses.

For each of these six life course types one would like to know at what average age transitions between marital statuses occur and what proportion of the population experience each of the six life courses. This is problematic given that life courses differ strongly between cohorts. Here, we try to solve this issue by constructing synthetic life courses (Willekens, 1999). Based on period-specific information, we estimate how life courses would evolve if the occurrence and timing of partnerrelated events that is observed in recent years would continue into the future. We made estimates based on two sources: officially published data of Statistics Netherlands, and survey data from the Netherlands Kinship Panel Study (NKPS) (Dykstra et al., 2005). In the first wave of the NKPS, information on life courses was collected from more than 8,000 persons, forming a representative sample of the Dutch population of age 15 and over. In Table 2, estimates of the average ages at which specific transitions occur are presented, whereas in Table 3 the distribution of

Table 2 Average age for different transitions in partner status, by sex

\begin{tabular}{lll}
\hline Event & Average age man & Average age woman \\
\hline First marriage & 26 & 23 \\
Divorce & 35 & 32 \\
& $($ After 9 years of marriage) & (After 9 years of marriage) \\
Remarriage & 38 & 36 \\
Widowhood & $(3$ years after divorce) & (4 years after divorce) \\
Death of never married individual & 71 & 69 \\
Death of married individual & 78 & 80 \\
Death of widowed individual & 76 & 82 \\
Death of divorced individual & 75 & 80 \\
\hline
\end{tabular}

Table 3 Distribution of the Dutch population by life course type and sex (in percentage of the total male and female population)

\begin{tabular}{llcc}
\hline Type & Sequence of events & Man & Woman \\
\hline I & Never married-death & 6 & 6 \\
II & Married-death & 48 & 20 \\
III & Married-widowed-death & 21 & 47 \\
IV & Married-divorced-death & 10 & 12 \\
V & Married-divorced-remarried-death & 9 & 3 \\
VI & Married-divorced-remarried-widowed-death & 3 & 9 \\
\hline
\end{tabular}


Table 4 Average Happiness score (scale $0-1$ ) according to partner status and sex

\begin{tabular}{lcc}
\hline Partner status & Men & Women \\
\hline Never married & 0.72 & 0.70 \\
Married & 0.79 & 0.75 \\
Divorced & 0.70 & 0.69 \\
Remarried & 0.76 & 0.72 \\
Widowed & 0.72 & 0.70 \\
\hline
\end{tabular}

the population across the six life course types is presented. ${ }^{5}$ Given that the ages at which men and women experience family-related life events differ quite substantially, these calculations are performed separately for men and women.

The final issue concerns the estimation of the happiness weights that need to be attached to each partner status position. To estimate these weights we used an abridged version of the Bradburn Affect Balance Scale that has been used in the NKSP. This version contains five items: three about negative affect and two about positive affect (Dykstra et al., 2005). We considered the questions about positive affect (feeling happy and composed and calm) and negative affect (feeling nervous, depressed and miserable and dejected) to be equally important. Therefore we used the answer to the question about happiness twice. We added the three positive scores and subtracted the negative ones and translated this score to a scale of zero to one. ${ }^{6}$ Table 4 presents the average happiness scores for each marital status position. These scores are in line with results from earlier research. Happiness scores are highest for those in their first marriage, followed by the remarried. Scores are substantially lower for the never married, the divorced and the widowed. In addition, happiness is lower among women. This is particularly true for happiness among married and remarried women, mirroring the fact that the gains from marriage are smaller for women than for men.

\subsection{Results}

Using the information from Tables 2 and 4, the number of HLY from age 18 onwards was calculated for each life course type. In Table 5 the results from this calculation are presented, again separately for men and women. From Table 5, it is clear that the preferable life course in terms of the number of HLY is to live with one spouse until death. Compared to people who never lived with a partner, the difference in HLY is more than six years for men and more than 4 years for women. This result clearly contradicts Epicurus' advice that it is best to refrain from marriage altogether. At the same time, Epicurus is right that marital break-up, either by divorce or widowhood leads to a reduction in HLY. Still, for all people who experienced marital break-up (Types III to VI), the number of HLY is at least equal to that of the never married. Only among people who experience a divorce and do not remarry, is HLY about equal to the HLY of the never married. From these results, it

\footnotetext{
5 These figures do not add up to $100 \%$, as a small proportion of people in the Netherlands experience life courses with multiple union formations and dissolutions. Their numbers are too small and their life courses too varied to allow further analysis.

${ }^{6}$ We also used an alternative method in which we constructed a Likert-scale based on the five items. The results hardly differed from the ones presented here.
} 
Table 5 Number of HLY after age 18, by life course type and sex

\begin{tabular}{llcc}
\hline Type & Sequence of events & Men & Women \\
\hline I & Never married-death & 40.1 & 43.1 \\
II & First marriage-death & 46.6 & 47.8 \\
III & Married-widowed-death & 44.7 & 46.4 \\
IV & Married-divorced-death & 40.9 & 43.2 \\
V & Married-divorced-remarried-death & 45.4 & 46.0 \\
VI & Married-divorced-remarried-widowed-death & 43.9 & 45.0 \\
\hline
\end{tabular}

seems safe to conclude that Epicurus' skepticism about marriage is not warranted. In present day society at least, the gains in happiness are greater than the costs. The desire for a partner cannot be classified as 'natural and unnecessary'.

In addition, comparing the HLY of men and women allow some interesting observations. First of all, it can be noted that the HLY of each life course type is higher for women than for men. This suggests that the higher life expectancy of women compensates for the lower level of happiness per year. Although women are less happy than men in almost every partner status, the final HLY are higher because they live longer than men. Second, the HLY of men and women following the most common life course type (type II for men and type III for women) hardly differ at all. In that sense, it seems that the lifetime happiness of men and women following the modal life course for their sex is more or less the same. Third, the difference in HLY between types I and II is smaller for women than for men. This results from two facts: women gain less happiness from marriage than men and the difference in life expectancy between the never married and the married is smaller for women than for men. Still, even women seem well advised not to pay too much attention to the teachings of Epicurus regarding family life.

\subsection{Limitations}

Finally, we would like to point out some of the limitations of this empirical exercise. A first limitation is that we did not differentiate happiness within partner statuses, for instance by age or by duration since the start of the status. It seems unlikely, however, that refining the analysis in this respect would yield results that are substantially different from the ones presented here. ${ }^{7}$

Another limitation is that we constructed synthetic life courses. It does not reflect the life course of specific cohorts, but rather assumes that patterns observed in the present time will hold for the future as well. Evidently, that will not necessarily be true. For instance, it might well be that the proportion of marriages ending in divorce will increase. If so, more people will follow life course types IV, V and VI, shifting the HLY of the total population downwards. A third issue relates to selection and causality. For example, it is reasonable to expect that selection processes partly determine who will get married and who will stay single all of their lives. Some of the people who stay unmarried may be selective on characteristics that increase the

\footnotetext{
${ }^{7}$ We checked this by applying a model in which the happiness weights for each partner status were allowed to vary by age, if a regression model showed that happiness for that partner status varied significantly by age. The results from this more complicated model differed little from the ones presented in Table 5.
}

算 Springer 
chances of unhappiness. If so, the impact of life events on HLY is overestimated. However, research has shown that marriage has a substantial protective effect, suggesting that even after controlling for selection, some differences in HLY between life course types would remain (Brockmann \& Klein, 2004; Lillard \& Waite, 1995).

A final limitation is that the analysis is about the average person. For specific individuals the costs of marriage may exceed the benefits, as seems to be the case in low quality marriages (Hawking \& Booth, 2005). These limitations notwithstanding, we believe that the analyses presented give added weight to our conclusion that Epicurus too rigidly advised people to be passive in life, for all he wanted them to do is to avoid pain. Sometimes it is better to go for specific pleasures as well.

\section{Discussion}

Epicurus showed a lot of confidence in his happiness advice. At the end of his Letter to Menoeceus he wrote: 'Practise these and the related precepts day and night, by yourself and with a like-minded friend, and you will never be disturbed either when awake or in sleep, and you will live as a god among men.' A more ambivalent picture arises from our assessment of the applicability of his happiness advice today.

\subsection{Recommendations that apply today}

It is positive that Epicurus mentions the importance of the bio-psychological needs of people, and that fulfilling these needs will contribute greatly to happiness. Also his observation that intimate relationships, and especially friendships enhance happiness more than materialism and status, stands the test of modern data. His advice to live a life with moderate and varied pleasures turns out to be valid, although he exaggerated the need for deferring gratification. His ideas about the importance of a healthy lifestyle seem to be correct as well. In these respects it won't do us any harm to follow his advice today.

\subsection{Recommendations that don't apply today}

However, there are two noticeable exceptions. Research findings do not support his advice to prefer friendship to marriage and to avoid public life. For this he offered the alternative of living in a commune of like-minded people. For his contemporaries this may have been enough compensation, given the societal turmoil of his time, but this way of life is not appropriate for present-day readers.

\subsection{Unnecessary unhappiness}

The value of Epicurus' advice, however, is not that he pointed to a unique direction that would always make people happy. The central aim of his philosophy is find a cure for 'unnecessary' unhappiness, that is the low well-being of people that have their basic needs fulfilled, but who still feel bad because they want things they cannot have. This advice shares many characteristics with modern day cognitive behavioral therapy that aims to cure counterproductive patterns of thinking and reacting and to replace them by more realistic and helpful ones. 
In Epicurus' happiness advice a lot of attention is given to the unchangeable stressors of life, such as death, disease, terrible pain and ill fate (the gods). He encourages his followers to confront these facts of life, without losing emotional equilibrium. The core of the self does not need to be touched by the hardships. We do not know how effective this approach is for the readers of his texts, but research about acceptance (Hayes, 2001) indicates that this may be a fruitful approach for dealing with difficult emotions.

However, Epicurus' focus on avoiding negative affect has two serious side effects if it is used as inspiration for dealing with life. The first is that Epicurus-for a hedonist-had a surprisingly negative view of positive affect. He conceived happiness as the absence of pain and this implied that there was little need to pursue positive experiences. Escaping pain was enough. This runs counter to what is known today about the active lifestyle of happy persons and about the independence of positive and negative affect. For the art of life, you need positive goals as well.

Epicurus' ideas about friendship and marriage can serve as an example in this respect. Epicurus advised people to focus on a wide circle of friends, and not on a specific bond with one spouse. The idea was that it is too dangerous to become dependent on one person, because of the pains of bad marriage, divorce or widowhood. With the help of a large Dutch survey study we were able to show that this risk avoidance is unwarranted. On average the number of HLY is greater for those that take the risk and became involved in family life. The same can be argued for involvement in public life. On average the yields of involvements more than compensate for the frustrations.

One additional omission that has to be noted is that Epicurus neglected personality differences. Personality is one of the strongest and most consistent predictors of subjective well-being (e.g. Diener et al., 1999). The happy individual is extravert, optimistic, and worry-free, has internal control, self-esteem and feels in control of his environment. Epicurus' happiness advice does not take personality into account. This might have been because he underestimated the importance of personality traits. Another reason may be that he focused on aspects his followers were able to change. His advice was aimed at overcoming one's fears and being in control of one's own life. A last possible reason may be that personality differences would have had repercussions for his commune in the Garden. It is easier to be an enlightened leader, if you do not have to fuss about personal preferences in life-style.

\subsection{Limitations to this approach}

The present study has several limitations. The first is that Epicurus' advice was aimed at his contemporaries, but we investigated the applicability for modern readers. Some of Epicurus 'mistakes' may have been caused by this transition. The second is that we used findings from general population surveys to judge the applicability of the advice. A better approach would be to empirically test if present day readers would actually benefit from reading Epicurus. A third limitation is that our judgment is based on our interpretation of Epicurus'philosophy, for which we often followed the lead of Annas (1993). It is an open question whether the average modern reader of Epicurus reads his admonitions in the same way. This question can only be answered by an empirical study and such a study would be worth undertaking, the philosophy of the good life being too important to leave it to intellectual speculation.

望 Springer 


\section{References}

Abbe, A., Tkach, C., \& Lyubomirsky, S. (2003). The art of living by dispositionally happy people. Journal of Happiness Studies, 4, 385-404.

Abueg, F. R., Follette, V. M., \& Ruzek, J. I. (2001). Cognitive-behavioral therapies for trauma. New York: Guilford Press.

Algra, K. A. (1998a). Epicurus en de filosofie. In Epicurus, Brief over Geluk. Groningen: Historische uitgeverij.

Algra, K. A. (1998b). Epicurus: Leven en school. In Epicurus, Over de natuur en het geluk. Groningen: Historische uitgeverij.

Annas, J. (1993). The morality of happiness. New York: Oxford University Press.

Baer, R. A. (2003). Mindfulness training as a clinical intervention: A conceptual and empirical review. Clinical Psychology: Science and Practice, 10, 125-143.

Bergsma, A. (1995). Emoties en kwaliteit van bestaan. Utrecht: Spectrum.

Bitsori, M., \& Galanakis, E. (2004). Epicurus death. World Journal of Urology, 22, 466-469.

Brennan, T. (1996). Epicurus on sex, marriage, and children. Classical Philology, 91(4), 346-352.

Brockmann, H., \& Klein, T. (2004). Love and death in Germany: The marital biography and its effect on mortality. Journal of Marriage and Family, 66, 567-581.

Brown, K. W., \& Ryan, R. M. (2003). The benefits of being present: Mindfulness and its role in psychological well-being. Journal of Personality and Social Psychology, 84, 822-848.

Cacioppo, J. T., \& Gardner, W. L. (1999). Emotion. Annual Review of Psychology, 50, 191-214.

Carver, C. S. (2003). Pleasure as a sign you can attend to something else; placing positive feelings in a general model of affect. Cognition and Emotion, 17(2), 241-261.

Chilton, C. W. (1960). Did Epicurus approve of marriage? A study of diogenes Laertius X 119. Phronesis, 5, 71-74.

Clark, A. E., \& Oswald, A. J. (2002). A simple statistical method for measuring how life events affect happiness. International Journal of Epidemiology, 31, 1139-1144.

Crombag, H., \& Van Dun, F. (1997). De Utopische verleiding. Amsterdam: Contact.

Csikszentmihaly, M. (1999). If we are so rich, why aren't we happy. American Psychologist, 54, 821827.

Danner, D. D., Snowdon, D. A., \& Friesen, W. V. (2001). Positive emotions in early life and longevity, findings from the nun study. Journal of Personality and Social Psychology, 90, 804813.

Diener, E., Suh, E., Lucas, R., \& Smith, H. (1999). Subjective well-being: Three decades of progress. Psychological Bulletin, 125, 276-302.

Dykstra, P. A., Kalmijn, M., Knijn, T. C. M., Komter, A. E., Liefbroer, A. C., \& Mulder, C. H. (2005). Codebook of the Netherlands Kinship Panel Study, a multi-actor, multi-method panel study on solidarity in family relationships, Wave 1. NKPS Working Paper No. 4. The Hague: Netherlands Interdisciplinary Demographic Institute.

Epicurus(1994). The Epicurus Reader, selected writings and testimonia. Indianapolis: Hackett.

Fordyce, M. W. (1977). Development of a program to increase personal happiness. Journal of Counseling Psychology, 24, 511-521.

Fordyce, M. W. (1983). A program to increase happiness: Further studies. Journal of Counseling Psychology, 30, 483-498.

Fredrickson, B. L. (1998). What good are positive emotions? Review of General Psychology, 2, 300319.

Fredrickson, B.L. (2001). The role of positive emotions in positive psychology. American Psychologist, 56, 218-227.

Frijda, N. H. (1988). De emoties; een overzicht van onderzoek en theorie. Amsterdam: Bert Bakker.

Glenn, N. D., \& Weaver, C. N. (1988). The changing relationship of marital status and happiness. Journal of Marriage and the Family, 50, 317-324.

Gross, J. J. (1998a). The emerging field of emotion regulation. Review of General Psychology, 2, 271299.

Gross, J. J. (1998b). Antecedent- and response-focused emotion regulation: Divergent consequences for experience, expression, and physiology. Journal of Personality and Social Psychology, 74, 224-237.

Gross, J. J., \& John, O. P. (2003). Individual differences in two emotion regulation processes: Implications for affect, relationships, and well-being. Journal of Personality and Social Psychology, 85, 348-362. 
Hawkins, D. N., \& Booth, A. (2005). Unhappily ever after: Effects of long-term, low-quality marriages on well-being. Social Forces, 84, 451-471.

Hayes, S. C. (2001). Acceptance and change, psychology of. In N. J. Smelser \& P. B. Baltes (Eds.), International Encyclopedia of the social and behavioral sciences. Amsterdam: Elsevier.

Hayes, S. C., Folette, V., \& Linehan, M. M. (Eds.) (2004). Mindfulness, acceptance, and the new behavior therapies: Expanding the cognitive-behavioral tradition. New York: Guilford Press.

Headey, B., \& Wearing, A. J. (1992). Understanding happiness, a theory of subjective well-being. Melbourne: Lonman Cheshire.

Hutchinson, D. S. (1994). Introduction. Epicurus, The Epicurus reader, selected writings and testimonia. Indianapolis: Hackett.

Jones, H. (1989). The Epicurean tradition. London: Routledge.

Kabat-Zinn, J. (2000). Indra's net at work: The mainstreaming of Dharma practice in society. In G. Watson \& S. Batchelor (Eds.), The psychology of awakening: Buddhism, science, and our dayto-day lives (pp. 225-249). Nork Beach, ME: Weiser.

Kamp Dush, C. M., \& Amato, P. R. (2005). Consequences of relationship status and quality for subjective well-being. Journal of Social \& Personal Relationships, 22, 607-627.

King, L. A., Hicks, J. A., Krull, J. L., \& Del Gaiso, A. K. (2006). Positive affect and the experience of meaning in life. Journal of Personality \& Social Psychology, 90, 179-196.

Kurdek, L. A. (1990). Divorce history and self-reported psychological distress in husbands and wives. Journal of Marriage and the Family, 52, 701-708.

Laertius, D. (1994). The life of Epicurus'. Epicurus, The Epicurus Reader, selected writings and testimonia. Indianapolis: Hackett.

McMahon, D. M. (2004). From the happiness of virtue to the virtue of happiness: 400 b.c.- a.d.1780. Daedalus, 133(2), 5-17.

Lazarus, R. S. (1991). Progress on a cognitive-motivational-relational theory of emotion. American Psychologist, 46(8), 819-834.

Lillard, L. A., \& Waite, L. J. (1995). 'Till death do us part': Marital disruption and mortality. American Journal of Sociology, 100, 1131-1156.

Long, A. A. (1986). Hellenistic philosophy, stoics, Epicureans. Berkeley and Los Angeles: University of California Press.

Lyubomirsky, S., King, L., \& Diener, E. (2005). The benefits of frequent positive affect: Does happiness lead to success? Psychological Bulletin, 131, 803-855.

Parducci, A. (1995). Happiness, pleasure and judgment; The contextual theory and its applications. Mahwah: Lawrence Erlbaum.

Peters, A., \& Liefbroer, A. C. (1997). Beyond marital status: Partner history and well-being in old age. Journal of Marriage and the Family, 59, 687-699.

Peterson, C., Park, N., \& Seligman, M. E. P. (2005). Orientations to happiness and life satisfaction; The full life versus the empty life. Journal of Happiness Studies, 6, 25-41.

Pressman, S. D., \& Cohen, S. (2005). Does positive affect influence health? Psychological Bulletin, 131, 925-971.

Rist, J. M. (1980). Epicurus on friendship. Classical Philology, 75, 121-129. .

Russell, B. (1948/1990). Geschiedenis der westerse filosofie: in verband met politieke en sociale omstandigheden van de oudste tijden tot heden. 's- Gravenhage; Servire.

Scheier, M. F., Carver, C. S., \& Bridges, M. W. (2001). Optimism, pessimism, and psychological wellbeing. In E. C. Chang (Ed.), Optimism and pessimism: Implications for theory, research, and practice. Washington D.C.: American Psychological Association.

Schmeichel, B. J., \& Baumeister, R. F. (2004). Self-regulatory strength. In R. F. Baumeister \& K. D. Vohs (Eds.), Handbook of self-regulation (pp. 84-98). New York: Guilford Press.

Segal, Z. V., Williams, J. M. G., \& Teasdale, J. D. (2002). Mindfulness-based cognitive therapy for depression: A new approach to preventing relapse. New York: Guilford Press.

Suh, E., Diener, E., \& Fujita, F. (1996). Events and subjective well-being: Only recent events matter. Journal of Personality and Social Psychology, 70, 1091-1102.

Tarn, W. W. (1952). Hellenistic civilisation. London: E. Arnold.

Veenhoven, R. (1996). Happy life-expectancy. A comprehensive measure of quality-of-life in nations. Social Indicators Research, 39, 1-58.

Veenhoven, R. (1999). Quality of Life in individualistic society. Social Indicators Research, 48, 157186.

Veenhoven, R. (2002). Het grootste geluk voor het grootste aantal, geluk als richtsnoer voor beleid. Rotterdam: Erasmus Universiteit.

Veenhoven, R. (2003). Hedonism and happiness. Journal of Happiness Studies, 4, 437-457. 
Veenhoven, R. (2006). World Database of Happiness: Continuous register of research on subjective appreciation of life. Website at Erasmus University Rotterdam, http://www.eur.nl/fsw/research/ happiness.

Ventegodt, S. (1996). Liskvalitet hos 4500 31-33-arige. (The Quality of Life of 4500 31-33-YearsOlds). Copenhagen: Forskningscentret Forlag.

Waite, L. J. (1995). Does marriage matter? Demography, 32, 483-507.

Willekens, F. J. (1999). The life course: Models and analysis. In L. J. G. van Wissen \& P. A. Dykstra (Eds.), Population issues. An interdisciplinary focus. New York: Plenum, 23-52. 